\title{
K-Means Algorithm and Binary Search on FiBuSI Application
}

Algoritma K-Means dan Binary Search pada Aplikasi FiBuSI

\author{
Ahmad Khuzaifi ${ }^{1}$, Ratih Titi Komala Sari ${ }^{2}$ \\ ${ }^{123}$ Informatika, Universitas Nasional Jakarta, Indonesia \\ 1*ahmadkhuzaifi20.ak@gmail.com ${ }^{2}$ ratih.titi@civitas.unas.ac.id \\ *corresponding author
}

\section{Informasi Artikel}

Received: August 2021

Revised: September 2021

Accepted: October 2021

Published: October 2021

\section{Abstract}

Purpose: Create an application called FiBuSI (Find Business and Stock Investment) using the $k$-means algorithm and binary search for data search features. This application is intended for entrepreneurs and investors where they can interact with each other to build a joint business.

Method: Using the RAD (Rapid Application Development) Method which focuses on system testing based on user experience related to Blackbox Testing using the Katalon Studio tools for testing functions on the FiBuSI application.

Result: Based on the results of testing the FiBuSI application which focuses on the success of application functions and algorithm implementation, that each application function is successfully executed (PASSED) based on testing using the Katalon Studio tools. Meanwhile, testing the k-means algorithm (data filter) and binary search (search for letter data) was also successfully carried out by testing it directly by the user on the FiBuSI application and also using the results from the Katalon Studio tools.

State of the art: Based on several studies that have been done previously related to the use of the k-means algorithm and binary search that this algorithm is carried out on 2 different features but in 1 application for business data search. In concept, the FiBuSI application focuses on bringing together entrepreneurs and investors in one platform. 
Keywords:information system; meeting minutes; speech recognition Kata kunci: sistem informasi; risalah rapat; speech recognition
Abstrak

Tujuan: Membuat sebuah aplikasi bernama FiBuSI (Find Business and Stock Investment) dengan menggunakan algoritma k-means dan binary search untuk fitur pencarin data. Aplikasi ini diperuntukkan untuk pengusaha dan investor dimana mereka bisa saling berinteraksi satu sama lain untuk membangun usaha bersama.

Metode: Menggunakan Metode RAD (Rapid Application Development) yang berfokus pada pengujian sistem berdasarkan pengalaman user yang berkaitan dengan Blackbox Testing menggunakan tools Katalon Studio untuk pengujian fungsi pada aplikasi FiBuSI.

Hasil: Berdasarkan hasil pengujian aplikasi FiBuSI ini yang berfokus pada keberhasilan fungsi aplikasi dan implementasi algoritma, bahwa setiap fungsi aplikasi berhasil dijalankan (PASSED) berdasarkan testing menggunakan tools Katalon Studio. Sementara untuk pengujian algoritma k-means (filter data) dan binary search (pencarian data perhuruf) juga berhasil dijalankan dengan mengujinya secara langsung oleh user pada aplikasi FiBuSI dan juga menggunakan hasil dari tools Katalon Studio.

State of the art: Berdasarkan beberapa penelitian yang telah dilakukan sebelumnya terkait penggunaan algoritma $k$-means dan binary search bahwa algoritma ini dilangsungkan pada 2 fitur yang berbeda namun dalam 1 aplikasi untuk pencarian data usaha. Pada konsepnya, aplikasi FiBuSI ini berfokus untuk mempertemukan pengusaha dan investor dalam satu wadah.

\section{Pendahuluan}

Masalah ekonomi selalu menjadi permasalahan yang seakan tidak ada habisnya. Persoalan yang datang silih berganti menghantam setiap sektor ekonomi yang secara langsung berdampak pada kehidupan sehari-hari. Dalam permasalahan ekonomi dapat diselesaikan dengan melihat perputaran arus uang, yaitu pada saat transaksi jual beli terjadi. Hal yang menjadi perhatian khusus adalah perputaran tercepat arus uang justru terjadi pada lingkup usaha kecil di masyarakat.

Ketika memulai usaha, kendala yang terjadi pada setiap pengusaha pada umumnya adalah keterbatasan modal yang dimiliki. Padahal modal yang cukup adalah awal dari terbangunnya suatu usaha sehingga dapat berjalan. Sementara di luar sana banyak investor yang memiliki modal namun belum bisa menyalurkan modalnya karena tidak berani memulai usaha atau belum menemukan orang yang tepat untuk bekerjasama dalam membangun usaha. Maka dari 
itu dibuatlah aplikasi ini yang diharapkan dapat mempertemukan pengusaha dan investor dalam satu wadah sehingga terjadi komunikasi dan bersama membangun usaha yang diinginkan.

Perancangan aplikasi ini akan menggunakan data mining yaitu salah satu teknik dalam menemukan pola yang terdapat pada suatu kelompok data. Pola yang telah ditemukan kemudian akan digunakan sebagai bahan pengambil keputusan [1]. Sedangkan algoritma yang diimplementasikan adalah k-means dimana banyak digunakan untuk menganalisis pengelompokkan data dengan bergantung pada nilai " $\mathrm{k}$ " sebagai kluster dan means yang merupakan rata-rata dari kluster tersebut [2]. Algortitma ini akan diterapkan dalam fitur "data filter" pada aplikasi dimana akan mengelompokkan data yang ada sebelum melakukan pencarian. Adapun kelebihan dari algoritma k-means yaitu mudah dilakukan, fleksibel dan menggunakan prinsip yang sederhana atau dapat dijelaskan dalam bentuk non-statistik. Namun kekurangannya yaitu terdapat kluster acak yang tidak memberikan kepastian terhadap pencarian kluster yang optimal.

Pada menu pencarian data pada penelitian kali ini menggunakan algoritma binary search yang banyak diimplementasikan untuk mendemonstrasikan pencarian nilai dalam urutan susunan elemen kelompok data. Dimana akan dilakukan pencarian terhadap array yang berurutan pada data yang tersedia [3]. Pada penerapannya, algoritma ini akan diimplementasikan pada fitur "pencarian data usaha" pada aplikasi yang akan dibuat. Kelebihan yang dimiliki algoritma ini diantaranya waktu yang dibutuhkan dalam melakukan pencarian lebih cepat terutama dalam jumlah data yang besar, komputasi yang dihasilkan juga relatif kecil. Sementara kekurangannya adalah algoritma yang digunakan cukup rumit dan data harus diurutkan terlebih dahulu. Dengan menggunakan kedua algoritma tersebut diharapkan akan memudahkan dalam proses pengolahan dan pencarian data usaha yang diinginkan.

Dari literatur riset terdahulu maka dibuat pengembangan algoritma yang diterapkan pada aplikasi FiBuSI (Find Business and Stock Investment) dimana aplikasi ini membantu para investor dan pengusaha untuk saling bersinergi dalam mengembangkan bisnisnya.

\section{Metode Penelitian}

Metode RAD (Rapid Application Development) adalah proses perancangan dan pengembangan sebuah perangkat lunak atau aplikasi dimana perkembangan dilakukan dengan waktu yang singkat (dapat diperkirakan 60 - 90 hari) dengan menggunakan pendekatan konstruksi yang berbasis pada komponen aplikasi tersebut [9]. Metode ini berfokus pada pengembangan aplikasi melalui pengulangan yang dilakukan berulang dengan mengandalkan feedback dari pandangan user. Berdasarkan metode RAD tersebut, maka tahapan aplikasi ini terlihat pada Gambar 1. 


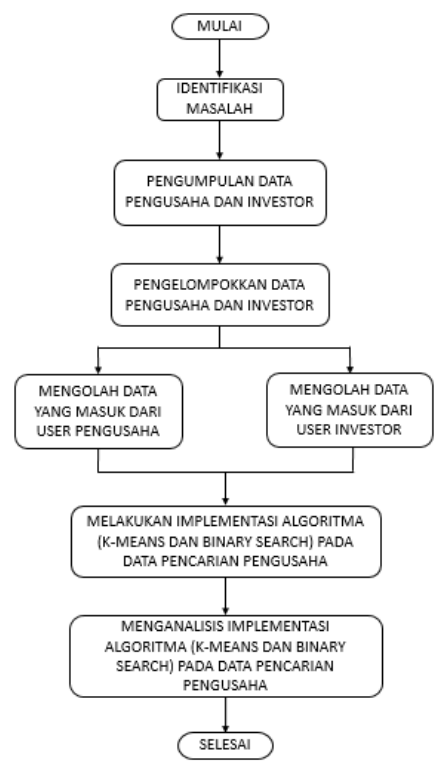

Gambar 1. Penelitian dengan Model RAD

\subsection{Studi Literatur}

\subsubsection{Data Mining}

Merupakan suatu proses yang dilewati untuk membuat suatu keputusan menggunakan teknik statistika yang diekstraksi dalam daftar data yang sebelumnya tidak diketahui namun sudah dipahami terlebih dahulu [4]. Data Mining bisa juga disebut dengan proses menemukan pola yang tersembunyi di dalam data. Intinya fungsi dari data mining adalah untuk memahami lebih jauh mengenai data yang menjadi objek penelitian untuk kemudian menemukan pola yang terdapat dalam data tersebut.

\subsubsection{Clustering}

Clustering adalah salah satu dari metode pengelompokkan data dan diubah menjadi banyak kelompok sampai data di dalamnya mempunyai tingkat kesamaan tinggi dan rendah pada kelompok lainnya. Clustering terdapat dalam kehidupan sehari-hari karena tidak dapat dipisahkan dengan sejumlah data yang menghasilkan informasi untuk kepentingan pengambilan keputusan sehingga diperlukan pengklasifikasian data ke dalam satu cluster atau kelompok [5].

\subsubsection{Algoritma K-means}

Merupakan algoritma clustering yang menggunakan jarak sebagai metrik dengan memberikan kelas k ke dalam kumpulan data, lalu memberikan pusat awal untuk menghitung nilai rata-rata aritmetik dari sebuah bentuk obyek yang disebut centroid [6].

Adapun tahapan untuk melakukan clustering dengan algoritma $k$-means adalah :

1. Cluster $k$ yang akan dibuat ditentukan terlebih dahulu.

2. Memberikan inisialisasi nilai acak terhadap pusat-pusat cluster yang ada, nilai acak ini disebut centroid. Metode ini sering digunakan dalam pemberian nilai pada cluster. 
3. Memindahkan seluruh data ke cluster yang terdekat. Dapat dikatakan dekat ketika dua objek ditentukan oleh jarak keduanya, juga kedekatan data ditentukan oleh jarak data dan pusat cluster. Ini adalah contoh pemberian jarak pada 2 cluster :

10

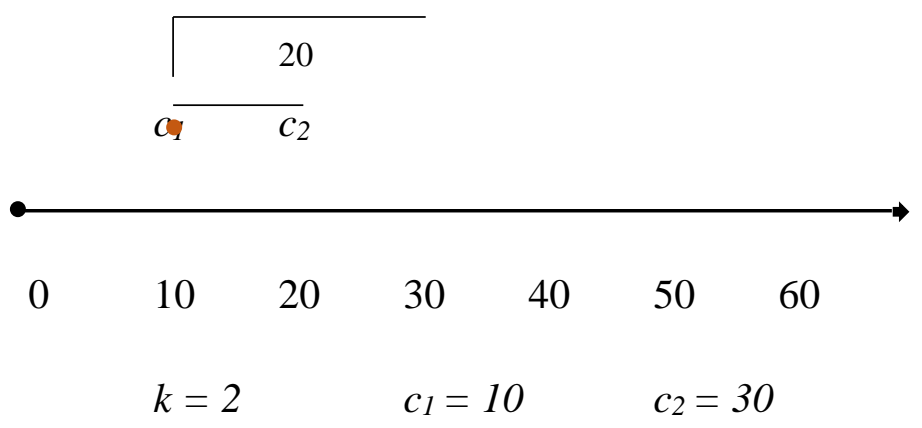

dimana :

$k \quad=$ Cluster

$c_{1}=$ Centroid 1

$c_{2}=$ Centroid 2

- $\quad=$ Data angka pada objek

Rumus teori jarak Euclidean dapat digunakan untuk perhitungan keseluruhan data jarak menuju titik pusat cluster.

$D(i, j)=\sqrt{ }(X 1 i-X 1 j) 2)+(x 2 i-X 2 j) 2+\cdots+(X k i-X k j) 2$

\subsubsection{Algoritma Binary Search}

Adalah algoritma yang digunakan dalam pencarian data terurut. Pada penelitian yang dilakukan oleh Riski Muhamad Fitrian dan rekannya [8], sebenarnya dalam kehidupan seharihari pencarian biner ini sering diterapkan contohnya untuk menemukan arti kata tertentu dalam kamus (seperti kamus bahasa Inggris). Untuk menemukan arti kata, tidak perlu membuka kamus dari halaman awal hingga akhir halaman satu persatu, tetapi carilah dengan memisahkan atau membaginya menjadi dua bagian. Jika kata yang dicari tidak terletak di tengah halaman, maka lihat kembali sisi kanan atau kiri dengan membaginya menjadi dua bagian dan begitu seterusnya sampai kata yang dimaksud berhasil ditemukan. Namun ini dapat dijalankan jika kata dalam data tersebut diurutkan.

Cara kerja pencarian adalah dengan mengurtkan data dalam array dan membaginya menjadi dua. Untuk memudahkan pembahasan, maka elemen array diurutkan (descending).proses 
pencarian, diperlukan dua indeks array dimana indeks terkecil terletak pada ujung kiri, sementara indeks terbesar pada ujung kanan dengan asumsi elemen berbentuk horizontal.

1. Berikut merupakan langkah-langkah dan rumus untuk mencari elemen dengan binary search :-Menggunakan rumus = posisi awal + posisi akhir $/ 2$ (untuk mencari data tengah).

2. Lakukan pembandingan data yang dicari dengan hasil data tengah pada langkah awal.

3. Apabila hasilnya lebih kecil :

Maka proses looping terus dilakukan, namun posisi akhir = posisi tengah -1 .

4. Apabila hasilnya lebih besar :

Proses looping kembali dilakukan, namun posisi awal diasumsikan $=$ posisi tengah +1 .

5. Proses ini akan terus dilakukan sampai ditemukan kesamaan antara data yang dicari dengan data tengah.

\subsubsection{Unified Modelling Language (UML)}

Adalah salah satu alat untuk mengembangkan sistem yang berhubungan dengan obyek dalam pemodelan secara visual. Terdapat banyak tipe diagram UML ini, diantaranya adalah:

\section{Usecase Diagram}

Adalah fungsi yang disediakan oleh sistem yang menunjukkan hubungan antar user sebagai unit yang saling bertukar pesan.

2. Activity Diagram

Merupakan suatu pemodelan proses dengan mengurutkan kegiatan dalam sistem yang menunjukkan perubahan pada setiap aktivitas yang terjadi.

\subsubsection{Black Box Testing}

Adalah salah satu teknik pengujian fungsional pada perangkat lunak. Maksud pengujian dari segi fungsional adalah dengan melakukan pengujian dari sudut pandang pengguna ketika mencoba untuk mengoperasikan aplikasi tersebut[10]. Untuk teknik pengujian pada penelitian kali ini menggunakan aplikasi Katalon Studio versi 8.2.0, yang merupakan salah satu tools pengujian untuk aplikasi berbasis Web, Mobile App, API dan lainnya.

\section{Hasil dan Pembahasan}

\subsection{Sistem dan Desain Software}

Pada bagian ini merupakan proses dimana hasil analisa kebutuhan akan dirubah menjadi bentuk visual. Dengan pemodelan UML (Unified Modelling Language) yaitu Usecase Diagram dan Activity Diagram.

\subsubsection{Analisa Kebutuhan Aplikasi}

Tahapan awal dalam perancangan sebuah aplikasi adalah dengan menentukan tools dan teknologi yang dipakai. Tujuannya adalah memudahkan proses pengerjaan aplikasi dengan mengetahui batas dan keperluan yang dibutuhkan. Kebutuhan perancangan aplikasi FiBuSI ini terlihat pada Tabel 1 . 
Tabel 1. Kebutuhan Perancangan Aplikasi

\begin{tabular}{cll}
\hline No. & \multicolumn{1}{c}{ Aspek } & \multicolumn{1}{c}{ Spesifikasi } \\
\hline 1. & Jenis Aplikasi & Web Application \\
\hline 1. & Bahasa Pemrograman & PhP, HTML, Javascript, CSS \\
\hline 2. & Framework & CodeIgniter 3 \\
\hline 3. & Server & XAMPP \\
\hline 4. & Database & MariaDB \\
\hline 5. & Browser & Chrome, Firefox \\
\hline
\end{tabular}

\subsection{Pemodelan UML (Unified Modelling Language)}

\subsection{Usecase Diagram}

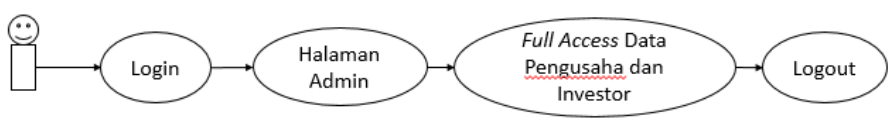

Gambar 1. User Admin

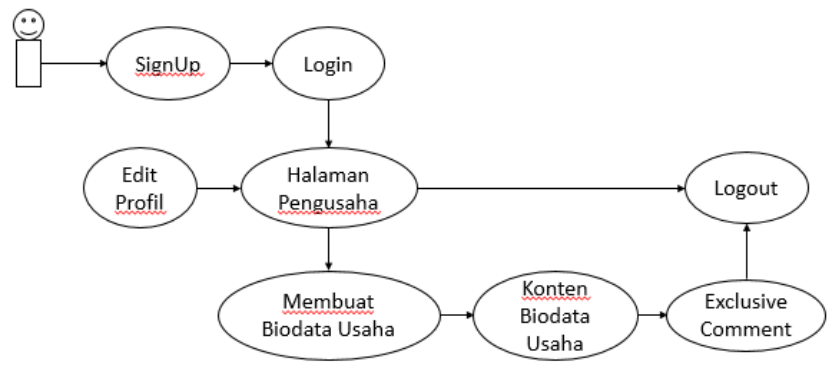

Gambar 2. User Pengusaha

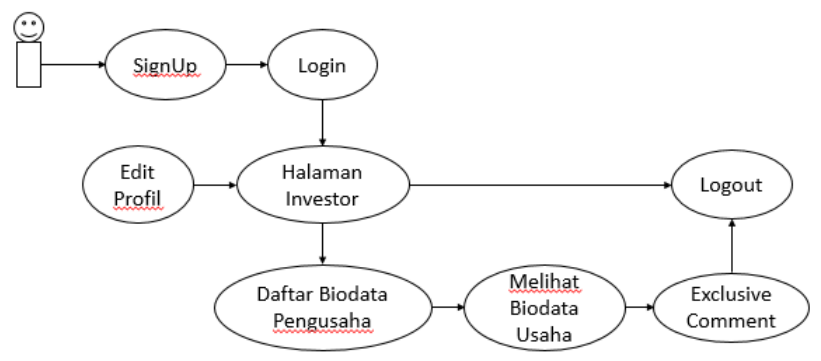

Gambar 3. User Investor 


\subsubsection{Activity Diagram}

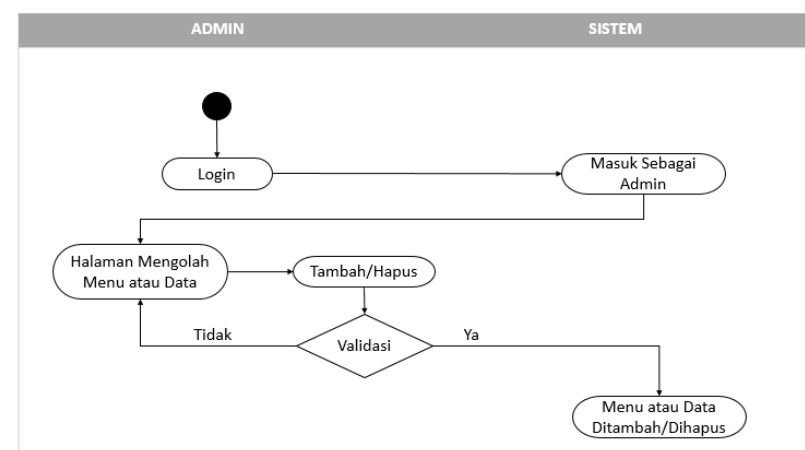

Gambar 4. Diagram Aktivitas Admin

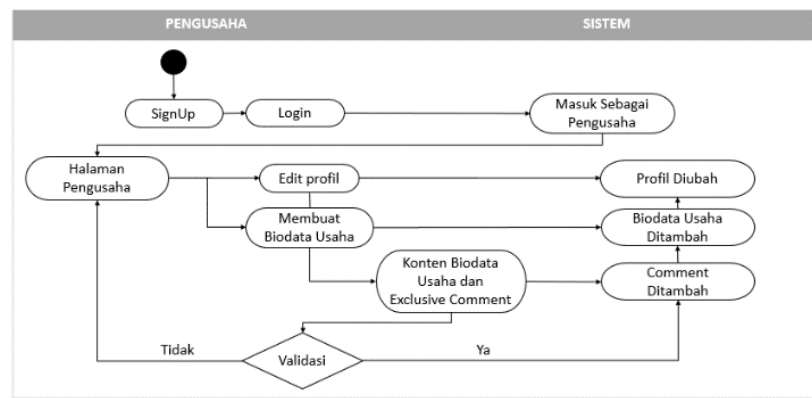

Gambar 5. Diagram AktivitasPengusaha

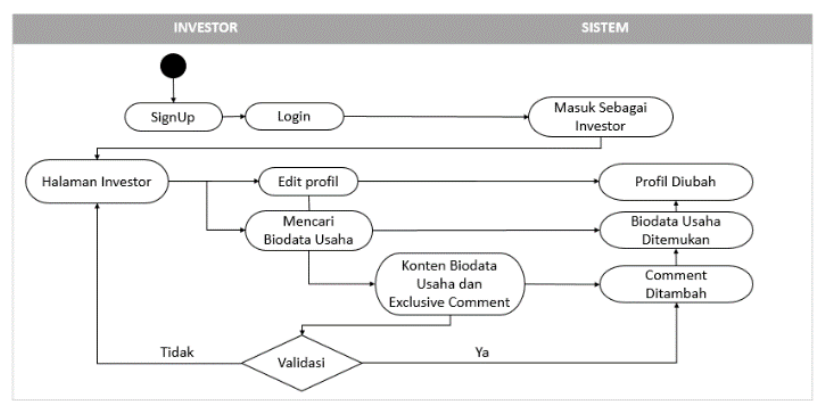

Gambar 6. Diagram Aktivitas Investor

\subsection{Implementasi dan Unit Testing}

\subsubsection{Halaman Login Aplikasi FiBuSI}

Merupakan halaman awal ketika user masuk ke dalam aplikasi FiBuSI ini dan login dengan menggunakan email dan password. 


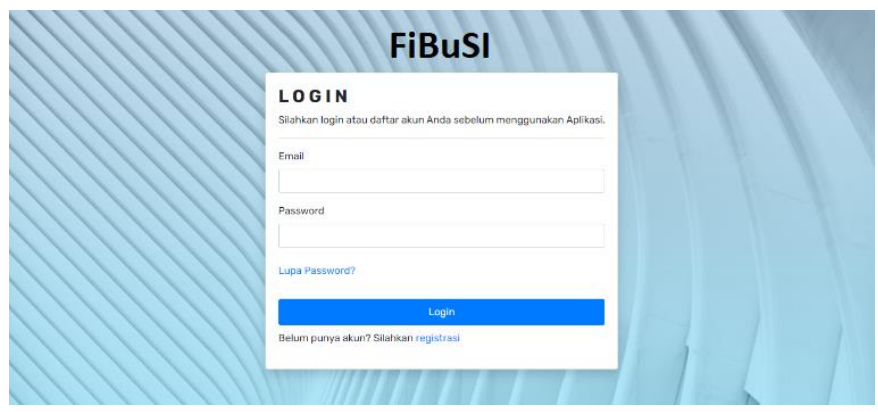

Gambar 7. Halaman Login

\subsubsection{Halaman Registrasi}

Halaman registrasi ditujukan untuk user yang belum memiliki akun (investor atau pengusaha) untuk kemudian menginput data yang diminta.

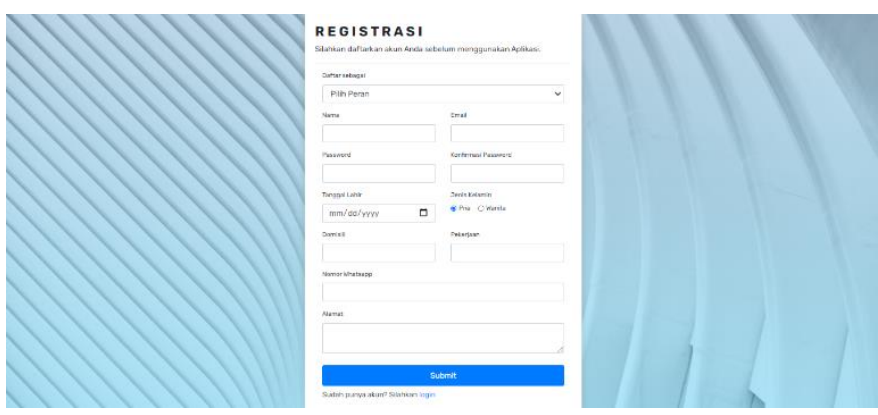

Gambar 8. Halaman Registrasi

\subsubsection{Halaman Lupa Password}

Halaman ini berada di halaman login, dan digunakan untuk meminta dikirimkan password yang baru lewat email yang sudah terdaftar sebelumnya.

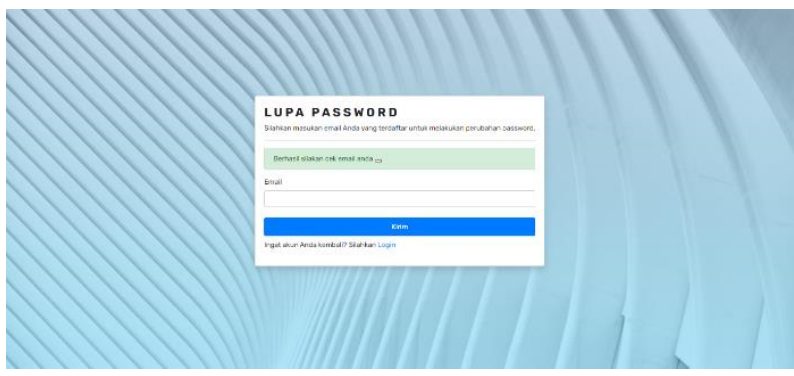

Gambar 9. Halaman Lupa Password

\subsubsection{Halaman Admin}

Halaman admin diperuntukkan khusus untuk admin pengelola yang sudah dibuat pada aplikasi FiBuSI untuk melakukan pengecekan dan penghapusan apabila terdapat data yang tidak sesuai ketentuan. 


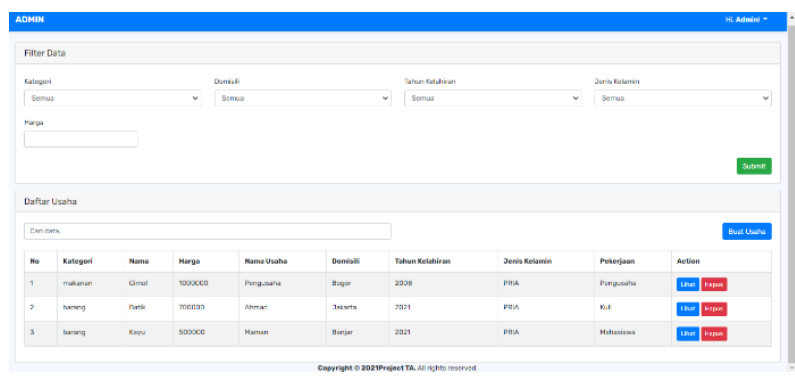

Gambar 10. Halaman Admin

\subsubsection{Halaman Pengusaha dan Buat Data Usaha}

Halaman pengusaha (Gambar 12) akan terbuka saat user berhasil login atau registrasi dengan menggunakan peran sebagai pengusaha. Kemudian di dalam halaman tersebut terdapat fitur tombol "Buat Usaha" (Gambar 13) untuk menginput ide usaha yang dimiliki. User pengusaha juga dapat mengupload file gambar, video atau powerpoint saat mengisi data usaha.

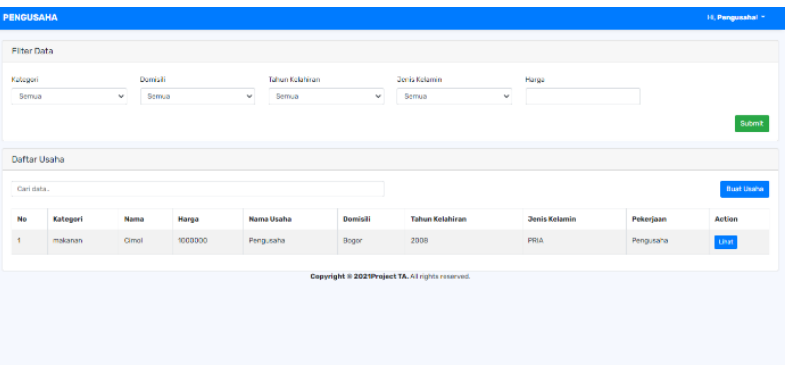

Gambar 12. Halaman Pengusaha

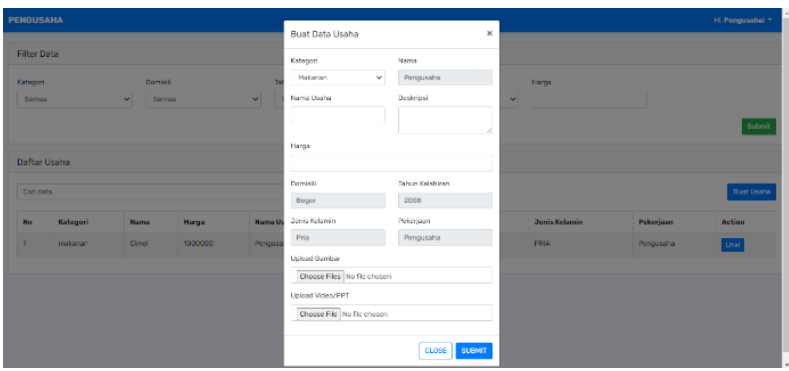

Gambar 13. Buat Data Usaha

\subsubsection{Halaman Data Usaha}

Halaman data usaha akan ditampilkan ketika user pengusaha berhasil membuat data usaha, kemudian mengklik fitur tombol action "Lihat" yang ada pada daftar usaha. Halaman ini berisi biodata usaha dan kontak pengusaha tersebut yang dapat dilihat oleh admin, pengusaha (yang memiliki usaha tersebut), dan investor. Selain itu, terdapat fitur komentar yang dapat digunakan untuk memberikan tanggapan terhadap usaha yang dibuat.

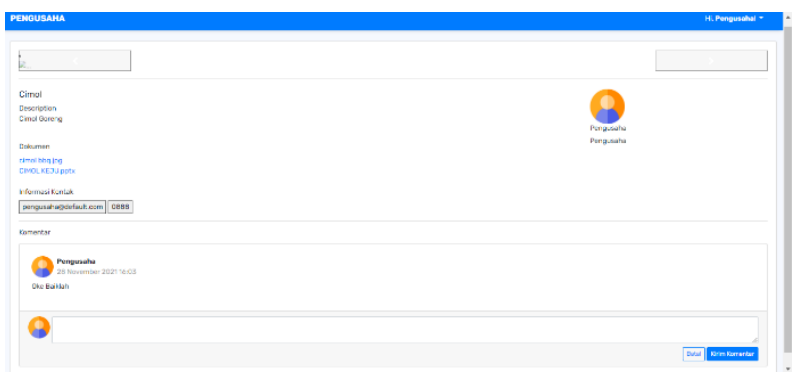

Gambar 14. Halaman Data Usaha

\subsubsection{Halaman Investor}

Halaman investor akan terbuka saat user berhasil login atau registrasi dengan menggunakan peran sebagai investor. Kemudian konten yang ditampilkan adalah berupa data pencarian (filter data dan pencarian manual) dan juga daftar usaha yang telah dibuat sebelumnya oleh pengusaha. 


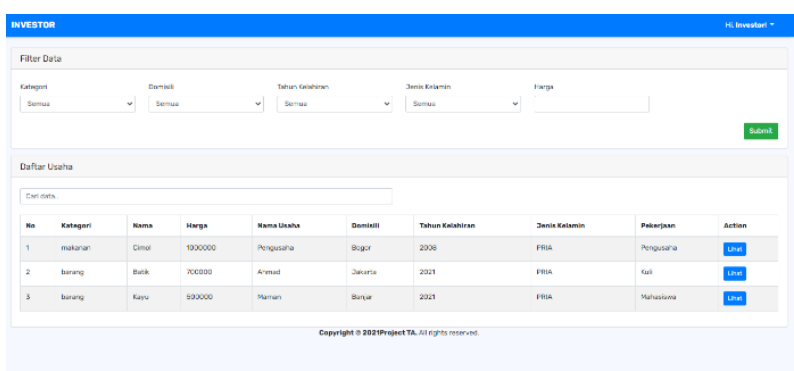

Gambar 15. Halaman Investor

\subsection{Implementasi Algoritma K-Means dan Binary Search}

\subsubsection{Fitur Filter Data (Algoritma K-Means)}

Pada penerapan algoritma ini didasarkan oleh 5 variable yaitu : kategori, domisili, tahun kelahiran, jenis kelamin, dan harga. Untuk mengetahui hasil dari implementasi algoritma KMeans dalam aplikasi ini akan mengambil contoh data variable domisili yang merupakan tempat asal pengusaha yang telah diinput ketika melakukan registrasi.

Tabel 2. Domisili Pengusaha

\begin{tabular}{llll} 
No. & Domisili & Jumlah & Cluster \\
\hline 1 & Jakarta & 4 & 1 \\
\hline 2 & Bandung & 2 & 2 \\
\hline 3 & Surabaya & 1 & 3 \\
\hline 4 & Palembang & 1 & 4 \\
\hline 5 & Yogyakarta & 1 & 5 \\
\hline
\end{tabular}

Pada Tabel 2 terlihat bahwa domisili terbanyak ada di "Jakarta" dengan nama cluster 1 dan domisili terendah yaitu ada di "Surabaya", "Palembang", dan "Yogyakarta" dengan nama masing-masing cluster 3, 4, dan 5 secara berurutan. Kemudian untuk implementasi source code untuk domisili yang digunakan diperlihatkan pada Gambar 16.

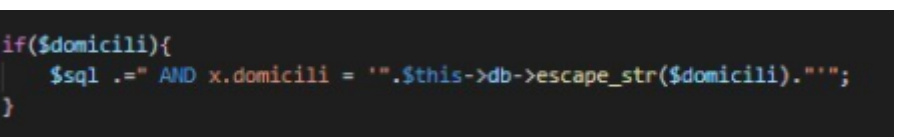

Gambar 16. Source Code Domisili

Setelah data nama domisili berhasil diinput dan masuk ke dalam database, maka fungsi ini akan menjalankannya dengan kondisi jika variable domisili dijalankan pada fitur filter data, maka akan otomatis menyajikan data domisili yang dicari dengan fungsi AND yang memungkinkan terdapat kondisi pada klausa WHERE. Kemudian diberikan fungsi escape_str untuk mengamankan basis data dari karakter yang tidak diketahui seperti tanda petik dan lainnya.

Pada Gambar 17 terlihat bahwa filter data domisili berhasil dilakukan dengan memilih domisili "Jakarta" dan data yang ditampilkan hanya data yang berdomisili dari "Jakarta". 


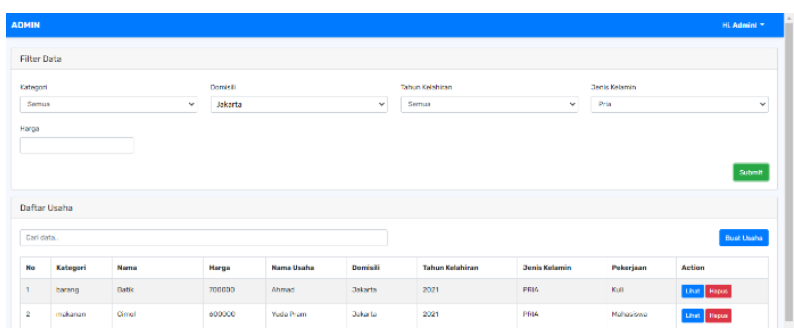

Gambar 17. Implementasi Filter Data dengan K-Means

\subsubsection{Algoritma Binary Search Pada Fitur Cari Data}

Dalam fitur pencarian data pada aplikasi ini, user dapat mengetikkan huruf atau kalimat ke dalam kolom pencarian. Dimana algoritma binary search akan mencari setiap data yang ada pada daftar usaha. Cara kerja dari algoritma ini adalah dengan membagi dua di antara kalimat yang dicari kemudian mencarinya dari kanan dan kiri sampai menemukan kecocokan huruf atau kalimat. Untuk implementasi source code yang digunakan diperlihatkan pada Gambar 18.

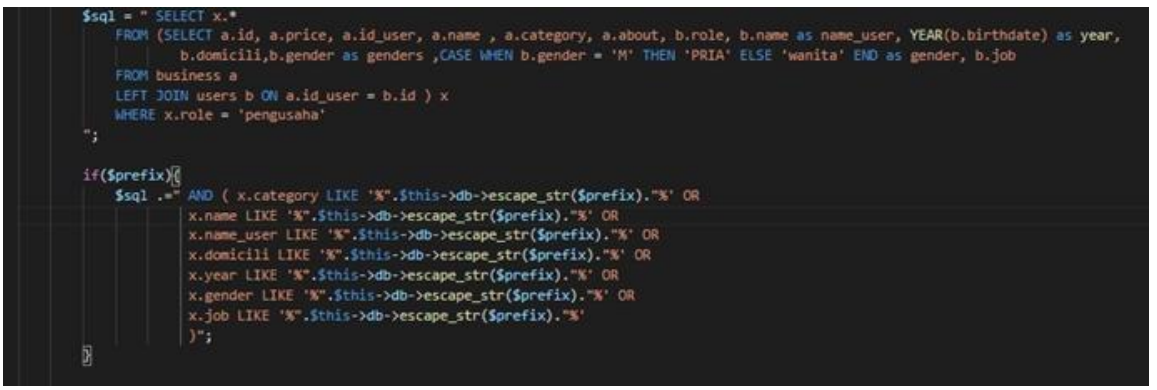

Gambar 18. Source Code Pencarian Data

Jika ada huruf atau kata diketikkan di kolom pencarian pada database (\$sql), maka fungsi akan dijalankan dengan mencari data yang ada pada variable : name, name_user, domicili, year, gender, dan job. Kemudian menggunakan operator LIKE yang berfungsi untuk menampilkan data berdasarkan pattern atau pola sesuai dengan kebutuhan. Adapun pattern yang digunakan adalah \% (percentage) yang akan mengecek string yang sesuai.

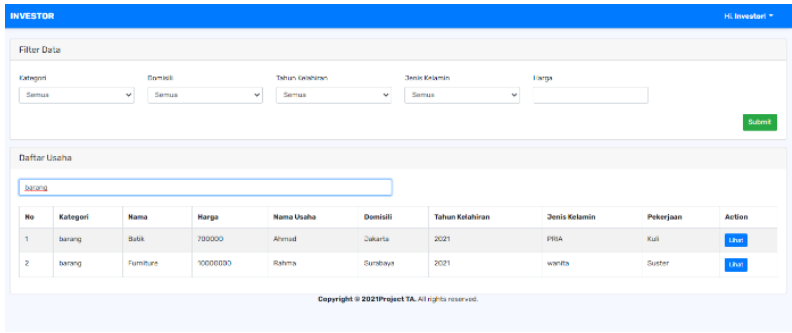

Gambar 19. Implementasi Pencarian Data dengan Binary Search

Terlihat pada gambar 19 berhasil dilakukan pencarian terhadap kalimat "barang" yang otomatis mencari huruf atau kata pada setiap bagian kolom daftar usaha. Hasilnya data yang ditampilkan adalah data yang hanya mengandung unsur "barang". Untuk pencarian polanya sendiri tidak harus sama persis dengan apa yang dicari seperti penggunaan huruf besar dan kecilnya sehingga memiliki keakuratan yang sangat baik. 


\subsection{Hasil Pengujian Aplikasi FiBuSI Dengan Katalon Studio}

Katalon Studio merupakan salah satu tools pengujian perangkat lunak yang banyak dipakai saat ini dan secara umum aplikasi ini membantu seorang untuk melakukan tester pada aplikasi. Cara kerja pada tools ini adalah dengan merekam kegiatan user ketika mengakses sebuah aplikasi dan menjalankan fitur-fitur di dalamnya. Setalah itu rekaman dihentikan dan akan muncul hasil laporan yang berisi kegiatan selama uji coba berlangsung. Hasil laporan pada tools ini menunjukkan ada 2 hasil, yaitu PASSED apabila fitur pada aplikasi berfungsi dengan baik dan FAILED apabila terjadi kesalahan atau error ketika menjalankan aplikasi. Pada penelitian kali ini dilakukan uji coba terhadap aplikasi FiBuSI dan hasil laporannya diperlihatkan pada Gambar 20, Gambar 21, dan Gambar 22.

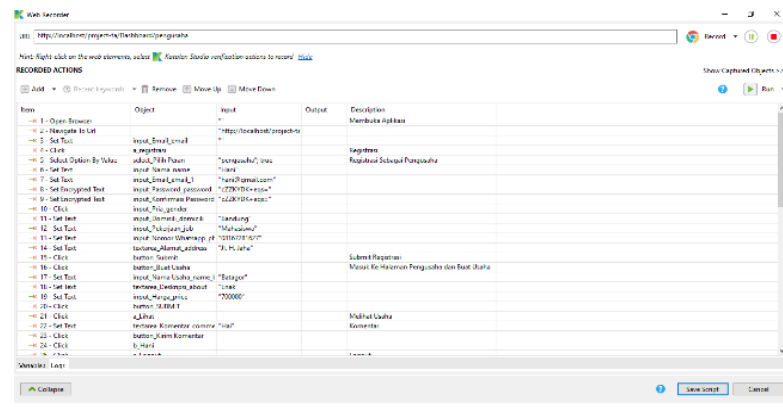

Gambar 20. Detail Hasil Uji Fitur Aplikasi (1)

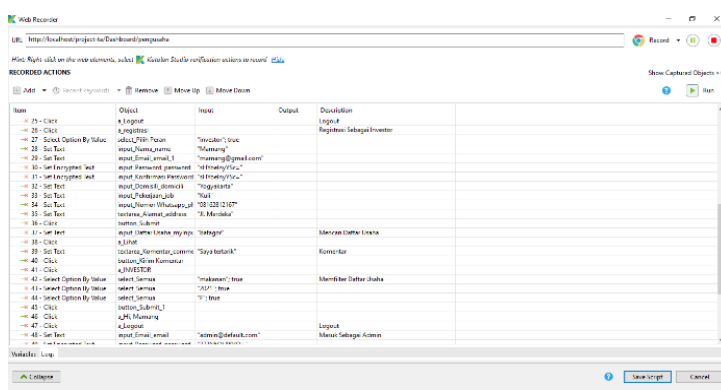

Gambar 21. Detai Hasil Uji Fitur Aplikasi (2)

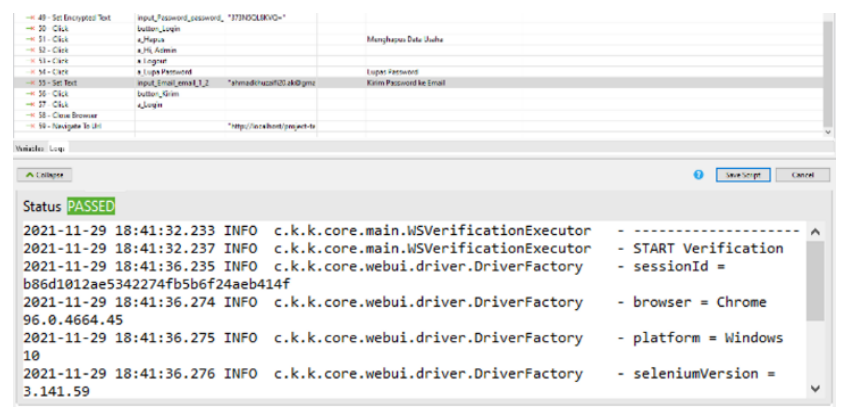

Gambar 22. Detail Hasil Uji Fitur Aplikasi (3) dan Hasil Laporan (PASSED)

\section{Kesimpulan dan Saran}

Berdasarkan pembahasan dan perancangan pembuatan aplikasi ini dapat disumpulkan bahwa setelah melakukan fungsi dengan menggunakan tools Katalon Studio versi 8.2.0 pada aplikasi FiBuSI, maka hasil yang didapatkan adalah PASSED (fitur pada aplikasi tersebut berhasil dijalankan). Fitur filter data dengan algoritma k-means lebih baik dalam pencarian data yang sudah dikelompokkan. Fitur pencarian data dengan algoritma binary search lebih baik dalam pencarian kata yang lebih spesifik (perhuruf atau kalimat). Pencarian data perhuruf atau kalimat tidak harus sama persis dengan data yang ada, seperti penggunaan huruf besar dan kecil sehingga lebih memudahkan dalam proses pencarian. Kekurangan pada kedua algoritma ini adalah ketika mencari data angka (khususnya untuk perkiraan harga budget) harus menginputkannya dengan spesifik sehingga data dapat ditemukan. 
Saran yang dapat diberikan pada penelitian aplikasi FiBuSI ini mengenai algoritma k-means dan binary search yang diterapkan mungkin dapat ditambahkan kembali variable yang digunakan untuk memudahkan pencarian data usaha. Pattern atau pola ketika melakukan input pencarian diharapkan lebih fleksibel lagi seperti menginput simbol selain angka dan huruf sehingga user dapat mencari data yang diperlukan tanpa menyesuaikan kaidah bahasa yang diinput ke dalam pencarian pada aplikasi ini.

\section{Daftar Pustaka}

[1] M. R. Muttaqin and M. Defriani, "Algoritma K-Means untuk Pengelompokan Topik Skripsi Mahasiswa," Ilk. J. Ilm., vol. 12, no. 2, pp. 121-129, 2020, doi: 10.33096/ilkom.v12i2.542.121-129.

[2] M. Ahmed, R. Seraj, and S. M. S. Islam, "The k-means algorithm: A comprehensive survey and performance evaluation," Electron., vol. 9, no. 8, pp. 1-12, 2020, doi: 10.3390/electronics9081295.

[3] S. Morshtein, R. Ettinger, and S. Tyszberowicz, "Verifying time complexity of binary search using Dafny," Electron. Proc. Theor. Comput. Sci. EPTCS, vol. 338, pp. 68-81, 2021, doi: 10.4204/EPTCS.338.9.

[4] A. E. Pramitasari and Y. Nataliani, "Perbandingan Clustering Karyawan Berdasarkan Nilai Kinerja Dengan Algoritma K-Means Dan Fuzzy C-Means," JATISI (Jurnal Tek. Inform. dan Sist. Informasi), vol. 8, no. 3, pp. 1119-1132, 2021, doi: 10.35957/jatisi.v8i3.957.

[5] F. M. Javed Mehedi Shamrat, Z. Tasnim, I. Mahmud, N. Jahan, and N. I. Nobel, "Application of k-means clustering algorithm to determine the density of demand of different kinds of jobs," Int. J. Sci. Technol. Res., vol. 9, no. 2, pp. 2550-2557, 2020.

[6] C. Yuan and H. Yang, "Research on K-Value Selection Method of K-Means Clustering Algorithm,” J, vol. 2, no. 2, pp. 226-235, 2019, doi: 10.3390/j2020016.

[7] S. Aulia, "Klasterisasi Pola Penjualan Pestisida Menggunakan Metode K-Means Clustering (Studi Kasus Di Toko Juanda Tani Kecamatan Hutabayu Raja)," Djtechno J. Teknol. Inf., vol. 1, no. 1, pp. 1-5, 2021, doi: 10.46576/djtechno.v1i1.964.

[8] R. M. Fitrian et al., "Digital Dictionary Using Binary Search Algorithm," J. Phys. Conf. Ser., vol. 1255, no. 1, 2019, doi: 10.1088/1742-6596/1255/1/012058.

[9] I. K. A. Wijaya, G. R. Dantes, and I. M. Candiasa, "Implementasi Sistem Pendukung Keputusan Pemilihan Guru dan Siswa Berprestasi dengan Kombinasi Metode Analytical Hierarchy Process dan Technique for Order Preference by Similarity to Ideal Solution," J. Nas. Pendidik. Tek. Inform., vol. 10, no. 2, p. 77, 2021, doi: 10.23887/janapati.v10i2.29386.

[10] M. Syarif, E. B. Pratama, U. Bina, S. Informatika, and K. Barat, "Testing dan Pemodelan Diagram Uml Pada Aplikasi Veterinary Services Yang Dikembangkan Dengan Model Waterfakk," J. Tek. Inform. Kaputama, vol. 5, no. 2, pp. 253-258, 2021. 